\title{
A Case of Laparoscopic Left Partial Nephrectomy with Concurrent Laparoscopic Sigmoidectomy
}

\section{Eş Zamanlı Yapılan Laparoskopik Sigmoidektomi ile Birlikte Laparoskopik Sol Parsiyel Nefrektomi Olgusu}

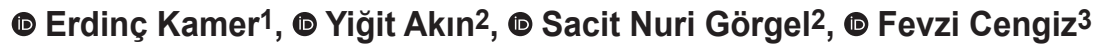 \\ 1 University of Health Sciences Turkey, İzmir Tepecik Training and Research Hospital, Clinic of Surgery, İzmir, Turkey \\ 2İzmir Katip Çelebi University Faculty of Medicine, Department of Urology, İzmir, Turkey \\ 3 İzmir Tınaztepe University, Clinics of Surgery, İzmir, Turkey
}

\section{HIIIIII| ABSTRACT}

Simultaneous laparoscopic procedures are now becoming more common, because of advances in laparoscopic surgery and greater laparoscopy experience for some clinicians. In this article, we present simultaneous laparoscopic sigmoidectomy and laparoscopic left partial nephrectomy in a 64-year-old female patient with sigmoid colon tumor and left renal angiomyolipoma.

Keywords: Laparoscopic surgery, sigmoid colon tumor, concurrent laparoscopy, angiomyolipoma

\section{|l|IIIII| ÖZ}

Eş zamanlı laparoskopik prosedürlerin uygulanması laparoskopik cerrahideki gelişmeler ve laparoskopi deneyiminin artmasına bağlı olarak günümüzde sıklıkla uygulanmaya başlanmıştır. Biz bu çalışmamızda sigmoid kolon tümörü ve solrenalanjiyomiyolipomu bulunan 64 yaşındaki kadın hastada eş zamanlı uyguladığımız laparoskopiksigmoidektomi ve laparoskopik sol parsiyelnefrektomi olgusunu sunmayı amaçladık.

Anahtar Kelimeler: Laparoskopik cerrahi, sigmoid kolon tümörü, eş zamanlı laparoskopi, anjiyomiyolipom

\section{Introduction}

Simultaneous laparoscopic procedures are now becoming more common, because of advances in laparoscopic surgery and greater laparoscopy experience for some clinicians. ${ }^{1,2}$ Although simultaneous procedures have been reported to prolong the operation time and anesthesia time and cause excessive blood loss, they also have the advantages of effective use of limited healthcare resources, reduced hospital stay, reduced postoperative pain, early return to work and good cosmetic results. ${ }^{3,4}$

Renal angiomyolipoma (AML) is a benign neoplasm arising from mesenchymal elements. AML was first reported in 1951. AML is also called a "hamartoma" because of its varying composition, including adipose tissue, smooth muscle, and blood vessels. ${ }^{5}$ Most AMLs are detected incidentally.
Hemorrhage (50-60\%) is most common in AML larger than $4 \mathrm{~cm}$. Hemorrhagic shock can be seen in approximately 30\% of patients who develop hemorrhage. In addition, although most AMLs are benign, a small proportion of them can show aggressive character. ${ }^{5}$ Symptomatic lesions smaller than 4 $\mathrm{cm}$ are followed up, while those that are symptomatic are treated with embolization or conservative surgery after angiography. While asymptomatic AMLs larger than $4 \mathrm{~cm}$ are followed up radiologically, angiography and selective arterial embolization, enucleation or partial nephrectomy treatments can be applied in symptomatic patients.

Jacobs et al. ${ }^{6}$ reported the first laparoscopic colectomy in the early 1990s. Compared to open surgery, laparoscopic colorectal surgery has some potential advantages. ${ }^{6}$

The aim of this case report is to describe a patient with sigmoid colon carcinoma and concurrent left kidney AML, in whom

Address for Correspondence/Yazışma Adresi: Erdinç Kamer, MD, Prof.

University of Health Sciences Turkey, İzmir Tepecik Training and Research Hospital, Clinic of Surgery, İzmir, Turkey

E-mail: erdinc.kamer@gmail.com ORCID ID: orcid.org/0000-0002-5084-5867

Received/Geliş Tarihi: 14.04.2021 Accepted/Kabul Tarihi: 31.05.2021

${ }^{\oplus}$ Copyright 2021 by Turkish Society of Colon and Rectal Surgery

Turkish Journal of Colorectal Disease published by Galenos Publishing House. 
successful simultaneous laparoscopic left hemicolectomy and left partial nephrectomy was performed.

\section{Case Report}

A sixty-four-year-old female patient was admitted to our hospital after a positive fecal occult blood (FOB) test during routine screening at the family health center. The patient's anamnesis, personal history and family history were unremarkable. The physical examination of the patient was normal, and there was no pathology evident on rectal examination. Informed consent was obtained and colonoscopy was performed because of the positive FOB test. Colonoscopy revealed a vegetative mass $20 \mathrm{~cm}$ away from the anal canal, with a length of $5-6 \mathrm{~cm}$ causing narrowing of the colon lumen, and biopsy was taken from the suspicious lesion. The biopsy result was reported as moderately differentiated adenocarcinoma. Except for a moderate low hemoglobin level (12.0 g/dL; normal range,
14-16 g/dL), the results of the complete blood count and blood biochemistry were normal. Carcinoembryonic antigen (CEA) level was $1.2 \mathrm{ng} / \mathrm{mL}$ (normal range 0-2.5 $\mathrm{ng} / \mathrm{dL}$ ). Computed tomography imaging of the patient, performed for staging, revealed irregular mucosa-wall thickening and lumen narrowing in the sigmoid colon and an AML with diameter $8.5 \mathrm{~cm}$, originating from the upper pole of the left kidney. Magnetic resonance imaging (MRI) was performed for the mass in the upper pole of the kidney (Figure 1). Simultaneous laparoscopic sigmoidectomy and laparoscopic left partial nephrectomy were planned in the same session with the involvement of the Urology team (YA, SNG). Ports were placed for classical laparoscopic sigmoidectomy. The medial dissection was completed by ligating the inferior mesenteric artery and vein. After the lateral dissection was completed, the splenic corner was cut. Thus, the left kidney lodge was also reached. Left partial nephrectomy was performed without inserting an
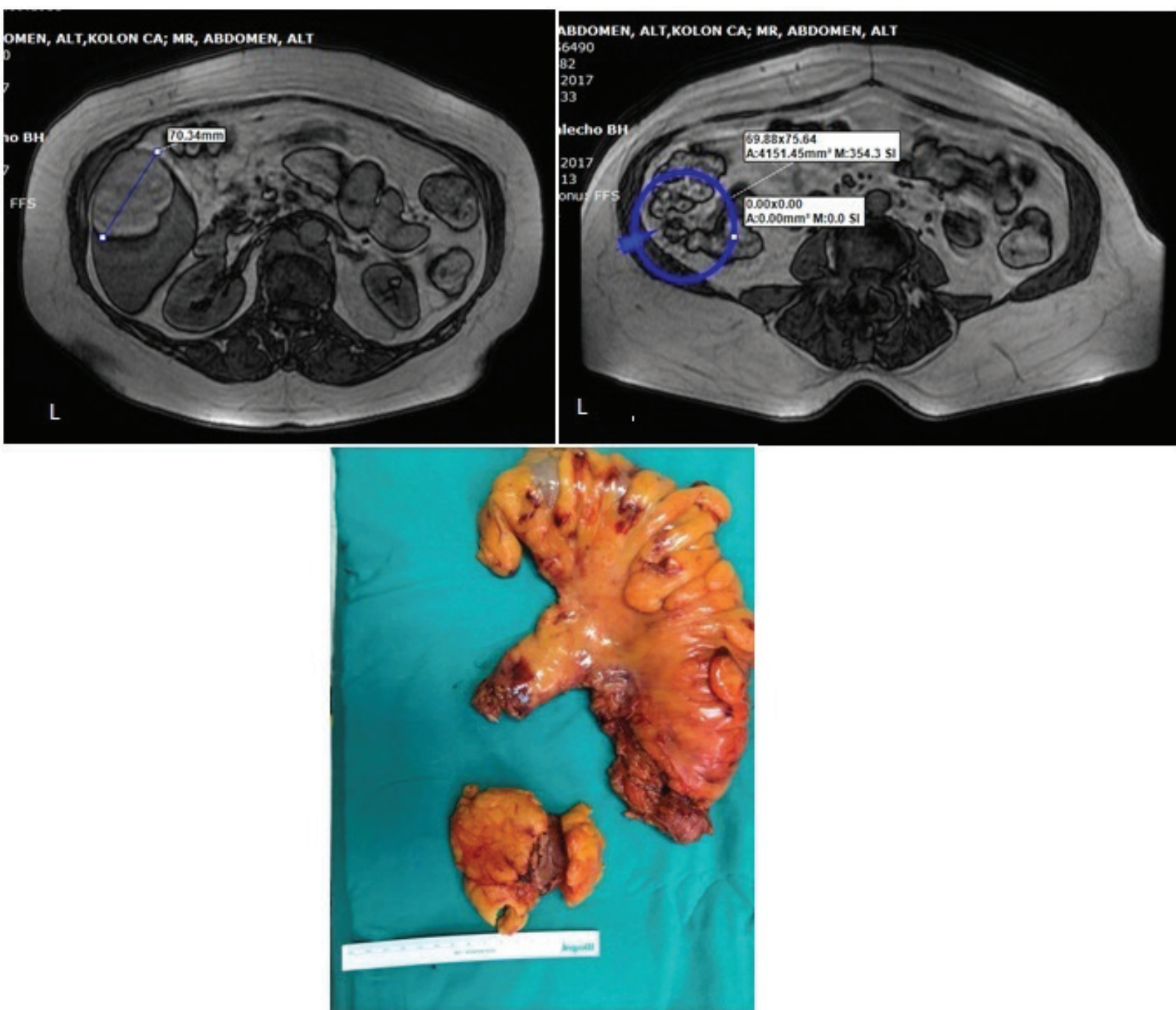

Figure 1. Left angiomyolipoma + sigmoid colon tumor image on MRI. Left sigmoidectomy + partial nephrectomy material in surgical specimen MRI: Magnetic resonance imaging 
additional port. Then, laparoscopic sigmoidectomy was completed (Figure 1). The patient's pathology was reported as moderately differentiated adenocarcinoma (T3NOTO) and AML. The patient was discharged on the fifth postoperative day without complications. No problem was encountered at the first and third month follow-ups. Postoperative adjuvant therapy was not considered.

\section{Discussion}

Colorectal cancer is one of the most common cancers in the world, and laparoscopic colectomy has been performed since 1991. ${ }^{2}$ Advances in minimally invasive surgery have now made it possible to safely perform several simultaneous surgical procedures. The benefits of minimally invasive surgery have also been extended to performing combined procedures for two different pathologies, concurrently simultaneously. This not only provides the benefits of minimally invasive surgery, but also provides benefits such as allowing the surgeon to perform simultaneous surgical procedures on two different accompanying pathologies, a single hospital stay, exposure to a single pre-anaesthetic evaluation, and a single anesthesia procedure for the patient. ${ }^{1,2}$ There are numerous reports of simultaneous operations, such as laparoscopic splenectomy, bariatric surgery, and hernia surgery performed during laparoscopic cholecystectomy, and urological operations such as laparoscopic simultaneous nephrectomy bilateral adrenalectomy, ureteropelvic stenosis and hernia repair being performed during laparoscopic cholecystectomy. ${ }^{3,7}$

Although the increasing use of cross-sectional imaging has increased the incidence of incidentally encountered AMLs, renal AMLs may cause spontaneous bleeding in 15\% and hemorrhagic shock in up to $10 \%$ of patients. Preservation of kidney function is important in patients with renal AML. Therefore, nephron-sparing surgery should be considered. A multidisciplinary meeting was held with general surgery, urology, radiology and medical oncology to plan the operation in the preoperative period, since our patient would have to undergo mandatory surgery due to a sigmoid colon tumor and the risk of bleeding was increased due to the fact that the patient would be operated in the left retroperitoneum. As a result of the council, simultaneous surgery was decided.

In conclusion, this report has shown that simultaneous laparoscopic left hemicolectomy and left partial nephrectomy is a feasible procedure in selected patients with sigmoid colon carcinoma and concurrent left kidney AML in centers with appropriate laparoscopic surgery experience.

\section{Ethics}

Informed Consent: Informed consent was obtained and colonoscopy was performed because of the positive FOB test.

Peer-review: Externally and internally peer reviewed.

\section{Authorship Contributions}

Surgical and Medical Practices: E.K., Concept: E.K., S.N.G., Design: E.K., Data Collection or Processing: E.K., Analysis or Interpretation: E.K., Y.A., F.C., Literature Search: E.K., Y.A., F.C., Writing: E.K.

Conflict of Interest: No conflict of interest was declared by the authors.

Financial Disclosure: The authors declared that this study received no financial support.

\section{References}

1. Kamlesh M, Sivanandam SE, Sukuma S, Bhat S, Kumar G, Nair B. Concomitant laparoscopic urological procedures: Does it contribute to morbidity? J Minim Access Surg 2009;5:67-71.

2. Wadhwa A, Chowbey PK, Sharma A, Khullar R, Soni V, Baijal M. Combined procedures in laparoscopic surgery. Surg Laparosc Endosc Percutan Tech 2003;13:382-386.

3. Savita KS, Khedkar I, Bhartia VK. Combined Procedures with Laparoscopic Cholecystectomy. Indian J Surg 2010;72:377-380.

4. Kamer E, Unalp HR, Derici H, Tansug T, Onal MA. Laparoscopic cholecystectomy accompanied by simultaneous umbilical hernia repair: A retrospective study. J Postgrad Med 2007;53:176-180.

5. Obin Ghimire, Li Wenzheng, Liu Huaping, Liu Wenguang, Pei Yigang, Hou Jiale. Angiomyolipoma of the Adrenal Gland: A Report of Two Cases and Review of the Literature. Am J Case Rep 2017; 18:989-994.

6. Jacobs M, Verdeja JC, Goldstein HS. Minimally invasive colon resection (laparoscopic colectomy). Surg Laparosc Endosc 1991;1:144-150.

7. Maurya K, Sivanandam SE, Sukumar S, Bhat S, Kumar G, Nair B. Concomitant laparoscopic urological procedures: Does it contribute to morbidity? J Minim Access Surg 2009;5:67-71. 